\title{
Expression and purification of a gene encoding a 9.7 kDa PE protein of Mycobacterium avium subsp. paratuberculosis
}

\author{
S. Chandra Sekar ${ }^{1} \cdot$ P. P. Goswami ${ }^{1} \cdot$ R. Deb ${ }^{1}$
}

Received: 12 July 2016/Accepted: 24 August 2016/Published online: 15 September 2016

(C) The Author(s) 2016. This article is published with open access at Springerlink.com

\begin{abstract}
Mycobacterium avium subsp. paratuberculosis (Map) contains PE family antigens which are Proline and glutamic acid rich and may play important role as T-cell antigens. In the present study, the Map 1507 ORF encoding 9.7 $\mathrm{kDa} \mathrm{PE}$ protein was amplified by polymerase chain reaction and cloned into $E$. coli vector pQE30 UA. The recombinant plasmid designated as $\mathrm{pQ} P E$ was transformed into E. coli M15 cells and induced with IPTG revealed the high level expression of $11.9 \mathrm{kDa}$ His-fusion protein as estimated by migration in $15 \%$ sodium dodecyl sulfate polyacrylamide gel electrophoresis (SDS-PAGE). Recombinant PE protein was purified by Ni-NTA agarose chromatography. Polyclonal antibodies raised against purified recombinant PE protein reacted with expressed PE protein as well as with Map sonicate. The recombinant PE protein was also recognized by serum from goat with clinical paratuberculosis. The protein elicited significant delayed type hypersensitivity (DTH) skin reaction in mice sensitized with Map. The results indicated that the recombinant PE protein of Map was associated with T-cell response.
\end{abstract}

Keywords Map $\cdot$ PE $\cdot$ pQE30 UA $\cdot$ Purification $\cdot$ DTH

P. P. Goswami

ppgnbc@yahho.co.in

1 Division of Veterinary Biotechnology, ICAR-Indian

Veterinary Research Institute, Izatnagar 243122,

Uttar Pradesh, India

\section{Introduction}

The search for M.a.paratuberculosis (Map)-specific antigens for diagnostic or preventive therapy has led to the discovery of several immunoreactive proteins. Many of these proteins have homology to other mycobacterial antigens.

Little is known about the structure, function, or immunological response to the PE proteins encoded by the subfamily of PE genes found throughout the genome of $M$. tuberculosis and other mycobacteria (Khubaib et al. 2016; Deng et al. 2015; Fishbein et al. 2015; Brennan et al. 2005; Fleischmann et al. 2002). These PE genes encode proteins that range in size from $\sim 30$ to $\sim 110$ amino acids, and most contain a characteristic Pro-Glu (PE) amino acid motif near the $\mathrm{N}$ terminus. Similar sequences are found as the N-terminal domain of the larger subfamily of proteins that contain polymorphic glycine repeat sequences (PE_PGRS) (Brennan and Delogu 2002). Studies using reverse transcriptase PCR and microarray analyses (Fisher et al. 2002; Voskuil et al. 2004) revealed that certain PE genes are expressed by $M$. tuberculosis. It has also been reported that PE 35 gene that was found in RD1, a multigene region that is absent in Mycobacterium bovis BCG strains, can elicit an immune response (Brusasca et al. 2001). Mycobacterium avium genome contains only a few PE genes and no PE_PGRS genes (Parra et al. 2006).

Parra et al. (2006) have shown that a PE protein of $M$. avium is a potent $\mathrm{T}$ cell inducer and capable of eliciting significant amounts of IFN $\gamma$ in experimental mice model. Immunization of mice with a novel PE gene expressed by M. avium (MaPE) showed that a dominant T-cell immune response was elicited. Immunization with a MaPE DNA vaccine protected mice against an aerosol challenge with Mycobacterium tuberculosis, suggesting that mycobacteria

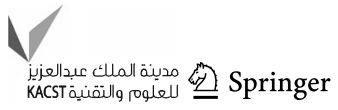


expressed PE antigens with cross-protective T-cell epitopes. Hence the identification and expression of PE antigen that stimulate $\mathrm{T}$ cell response seem to be an initial requirement for the development of effective vaccines and or CMI based diagnostic. The present communication deals with the cloning expression, purification and preliminary characterization of the $9.7 \mathrm{kDa} \mathrm{PE}$ protein of Map in E. coli.

\section{Materials and methods}

\section{Mycobacterial strains}

Bacterial strain of Map 316F were obtained from Central Diengenees Kunding Tieh Instituut, Lelystad, The Netherlands in Biological Products Division of IVRI, Izatnagar, and later maintained at Gene Expression lab, Division of Animal Biotechnology. IVRI, Izatnagar.

\section{Plasmid and host strains}

pTZ57R/T Cloning vector and host strain DH5 $\alpha$ of E. coli were supplied by MBI Fermentas, Germany. Prokaryotic expression vector pQE30UA was purchased from QIAGEN, Germany.

\section{Laboratory animals}

Swiss albino mice and New Zealand white rabbits were obtained from Laboratory Animal Resource Section, IVRI, Izatnagar. Standard prescribed guidelines for care and use of laboratory animals were followed during the experimentation with these animals.

\section{Culture and growth of Map and E. coli}

Map organisms were grown on Middlebrook 7H10 agar enriched with $0.1 \%$ glycerol $\mathrm{v} / \mathrm{v}$ and $10 \%$ oleic acid dextrose catalase (OADC) with additional supplementation of Mycobactin $\mathrm{J}(2 \mathrm{mg} / \mathrm{l})$ and were maintained at $37{ }^{\circ} \mathrm{C}$. E. coli cells were grown in Luria-Bertani (LB) medium at $37{ }^{\circ} \mathrm{C}$ with shaking at $180 \mathrm{rpm}$. For the preparation of LB plates, $1.5 \%$ agar powder was added to LB medium prior to autoclaving. Appropriate antibiotics were included as per requirements.

\section{Isolation of genomic DNA form Map}

The genomic DNA from Map was isolated by the method of Portillo et al. (1991) with a few modifications. The bacterial colonies were scrapped from 2-month-old Middle brook $7 \mathrm{H} 10$ agar slants in $1.5 \mathrm{ml}$ microfuge tube, washed thrice with $1 \mathrm{X}$ TE and resuspended in $500 \mu \mathrm{l}$ of $1 \mathrm{X}$ TE. Lysozyme was added to the final concentration of $5 \mathrm{mg} / \mathrm{ml}$ and incubated at $37^{\circ} \mathrm{C}$ for $2 \mathrm{~h}$. SDS and proteinase K were added to a final concentration of $1 \%$ and $250 \mu \mathrm{g} / \mathrm{ml}$, respectively, and incubated further at $65{ }^{\circ} \mathrm{C}$ for $30 \mathrm{~min}$. To this, $80 \mu \mathrm{l}$ of $5 \mathrm{M} \mathrm{NaCl}$ was added and vortexed. This was followed by addition of $64 \mu \mathrm{l}$ of $\mathrm{CTAB} / \mathrm{NaCl}$ solution and vortexed. The suspension was again incubated at $65^{\circ} \mathrm{C}$ for $30 \mathrm{~min}$. DNA was extracted once with phenol, once with phenol: chloroform (1:1) and finally with chloroform: isoamyl alcohol (24:1). The aqueous phase containing DNA was pelleted by centrifugation and washed with $80 \%$ ethanol, dried and redissolved in $200 \mu \mathrm{l}$ of $1 \mathrm{X}$ TE. Contaminating RNA was removed from DNA by incubating with $100 \mu \mathrm{g} / \mathrm{ml}$ RNase. The treatment was given for $1 \mathrm{~h}$ at $37{ }^{\circ} \mathrm{C}$, followed by phenol:chloroform extraction and ethanol precipitation.

\section{Cloning of $\mathrm{PE}$ gene in a prokaryotic expression vector $\mathrm{pQE30UA}$}

Specific amplification of the PE gene (Forward: $5^{\prime}-\mathrm{GCC}$ GCT AGC ATG TCG TTC GTG ACC ACA CA- $3^{\prime}$ and Reverse: $5^{\prime}$-GCC GAA TTC TCA GAG GGC CGC GGC GGC GT-3') from the genomic DNA of Map was carried in a $25 \mu \mathrm{l}$ reaction volume containing $1 \mu \mathrm{l}$ of genomic DNA (10 ng) as template, $2.5 \mu \mathrm{l}$ of PCR buffer, $\mu \mathrm{l}$ of $\mathrm{MgCl}_{2}$ $(1.5 \mathrm{mM}), 1 \mu \mathrm{l}(25 \mu \mathrm{M})$ of each primers, $1 \mu \mathrm{l}$ of dNTP mix (200 $\mu \mathrm{M}$ of each dNTP) and $1 \mathrm{U}$ of Taq DNA polymerase. The volume was made up to $25 \mu \mathrm{l}$ by adding DNase free water. The thermal cycling steps were carried out in PTC200 thermocycler MJ Research Inc, USA with initial denaturation at $94{ }^{\circ} \mathrm{C}$ for $5 \mathrm{~min}$ followed by 30 cycles with denaturation at $94{ }^{\circ} \mathrm{C}$ for $1 \mathrm{~min}$, annealing at $53.8^{\circ} \mathrm{C}$ for $1 \mathrm{~min}$, extension at $72{ }^{\circ} \mathrm{C}$ for $30 \mathrm{~s}$ and final extension at $72{ }^{\circ} \mathrm{C}$ for $10 \mathrm{~min}$. Size of the amplified product was confirmed by using DNA molecular weight marker in a $1.2 \%$ agarose gel and quantified by spectrophotometric analysis. The PCR amplified gene product was purified from agarose gel using a QIAEXII gel extraction kit (Qiagen, USA) and ligated to $\mathrm{pQE} 30 \mathrm{UA}$ expression vector the resulting plasmid designated as pQEPE. On transformation into E. coli M15 host cells the recombinant clones were selected on LB agar containing ampicillin $(100 \mu \mathrm{g} / \mathrm{ml})$ and kanamycin $(25 \mu \mathrm{g} / \mathrm{ml})$. Transformants were further screened by colony PCR, restriction enzyme analysis of the plasmids with NheI and EcoRI. Positive clones were send for sequencing. The nucleotide sequence of the $300 \mathrm{bp}$ gene fragment encoding $9.7 \mathrm{kDa} \mathrm{PE}$ protein from Map starin $316 \mathrm{~F}$ has been deposited in nucleotide database. The deduced amino acid sequence of the $9.7 \mathrm{kDa} \mathrm{PE}$ protein was analyzed for hydrophobic domains according to Kyte 
and Doolittle algorithm (Kyte and Doolittle 1982) using Lasergene software (DNASTAR, Madison, USA).

\section{Expression and purification of the recombinant PE protein}

Overnight grown cultures of the selected recombinant were inoculated in LB broth containing $(75 \mu \mathrm{g} / \mathrm{ml})$ and kanamycin $(25 \mu \mathrm{g} / \mathrm{ml})$. Once an optical density at $600 \mathrm{~nm}$ (OD 600 ) of the culture reached $0.6-0.7$, cells were induced with $1.0 \mathrm{mM}$ isopropyl thiogalactoside (IPTG) for 4-6 h. Whole-cell lysate of the bacterial were prepared and the expression of the recombinant PE protein from the induced and uninduced culture and $M 15$ cells were collected, lysed in sample buffer and stored at $-20{ }^{\circ} \mathrm{C}$ for SDS-PAGE. The purification of the recombinant PE protein $(9.7 \mathrm{kDa} P E$ and $2.2 \mathrm{kDa} \mathrm{N}$ terminal fusion domain of pQE30UA) was purified by $\mathrm{Ni}-\mathrm{NTA}$ (nickel-nitrilotriacetate) agarose affinity chromatography (Qiagen) After induction, cells $(0.5 \mathrm{~g})$ was lysed by stirring in lysis buffer $(6 \mathrm{M} \mathrm{GuHCl}$; $0.1 \mathrm{MNaH}_{2} \mathrm{PO}$; $0.01 \mathrm{M}$ Tris-Cl; $\mathrm{pH} 8.0$ ) for $30 \mathrm{~min}$, centrifuged at $10,000 \mathrm{~g}$ for $20 \mathrm{~min}$. Lysate was again mixed with $50 \%$ Ni-NTA slurry $(4: 1)$ and kept at $4{ }^{\circ} \mathrm{C}$ for $1 \mathrm{~h}$. Ni-NTA slurry was loaded on the column and finally the purified protein was eluted using elution buffer ( $8 \mathrm{M}$ Urea; $0.1 \mathrm{M} \mathrm{NaH}_{2} \mathrm{PO}_{4} ; 0.01 \mathrm{M}$ Tris-Cl; $\mathrm{pH} 4.5$ ) after washing with wash buffer ( $8 \mathrm{M}$ Urea; $0.1 \mathrm{M} \mathrm{NaH}_{2} \mathrm{PO}_{4} ; 0.01 \mathrm{M}$ Tris-Cl; pH 6.3 and $\mathrm{pH}$ 5.9). The fractions containing recombinant PE protein were extensively dialysed at $4{ }^{\circ} \mathrm{C}$ against PBS, to renature the protein. The protein concentration was determined spectrophotometrically. The protein solution was sterilized by filtration and aliquots were stored at $-70{ }^{\circ} \mathrm{C}$, until used.

\section{Hyper immunization for raising antisera against Map PE antigen}

Swiss albino, 6-8 weeks old mice, (six mice) were injected subcutaneously with $100 \mu \mathrm{g}$ of purified recombinant PE protein emulsified in incomplete Freund's adjuvant (IFA) (Genei, India). After 2 weeks subsequent two boosters were given at 2 weeks intervals. The mice were bled a week after the last dose and serum was collected later and stored at $-20{ }^{\circ} \mathrm{C}$ in aliquots for western blot analysis.

\section{Sero reactivity of $\mathrm{PE}$ antigen}

Expressed recombinant PE protein as well as Map sonicate were separated by $15 \%$ SDS-PAGE under reducing conditions and then electro blotted onto a nitrocellulose membrane $(0.45 \mu \mathrm{m})$ in a transfer buffer containing $48 \mathrm{mM}$ Tris- $\mathrm{HCl}, 39 \mathrm{mM}$ glycine, $0.037 \%$ SDS, and $20 \%$ methanol at $\mathrm{pH}$ 8.3, using a Semi-Dry Transfer
System (Atto, Tokyo, Japan) at $0.8 \mathrm{~mA} / \mathrm{cm}^{2}$, following the method of Bjerrum and Schaffer-Nielsen (1986). The blots were blocked with $2 \%$ skimmed milk powder in PBS-T buffer (PBS containing $0.1 \%$ Tween 20) for $2 \mathrm{~h}$ at room temperature. Immuno detection was carried out using polyclonal serum (1:2000, in PBS) raised in mice against recombinant PE protein followed by 1:500 dilution HRPlabeled rabbit anti-mouse IgG (Genei, India). Antigen was visualized on the blots by incubation with $0.02 \%$ diaminobenzidine (DAB) suspended in PBS containing $0.03 \%$ hydrogen peroxide. Further, about $25 \mu \mathrm{g}$ of recombinant PE protein in $25 \mu \mathrm{l}$ PBS and Map culture sonicate were put on nitrocellulose membrane dried and allowed to react with goat serum was obtained from a goat with clinical paratuberculosis as per the method described in western blot.

\section{Delayed hypersensitivity testing}

Thirty-six female Swiss albino mice (6-8 weeks old) into two groups consisting of eighteen animals each, the group I was subcutaneously injected with recombinant PE protein (100 $\mu \mathrm{g} / \mathrm{animal}$ in PBS) mixed with sterile incomplete Freund's adjuvant (IFA) (1:1), while the group II (control) was immunized with PBS-IFA alone. Two weeks after the second immunization, mice were injected, with a tuberculin syringe into the footpads, with $10 \mu \mathrm{g}$ of the recombinant PE protein or PPD (Purified Protein Derivative) in $0.02 \mathrm{ml}$ of PBS. Six mice each from both groups were also injected with $10 \mu \mathrm{lBS}$ as negative control. The results of the local skin reactions (DTH) were read after $48 \mathrm{~h}$ by measuring the two transverse diameters of erythema and swelling using Vernier calliper. Differences between swelling observed before and after protein injected in footpad and the swelling observed in PBS injected footpad were noted.

\section{Statistical analysis}

Data presented here are designated as mean \pm Standard error mean. One-way ANOVA was employed to evaluate the statistical differences among groups with SPSS 13.0 software (SPSS Inc., Chicago, IL, USA). A value of $P<0.05$ was considered as significant.

\section{Results}

\section{Heterologous expression of PE antigen of Map}

The PCR primers used in this study amplified a $318 \mathrm{bp}$ fragment (300 bp PE gene and 18 bp linker), which was cloned in pQE30UA vector and the resulting plasmid 


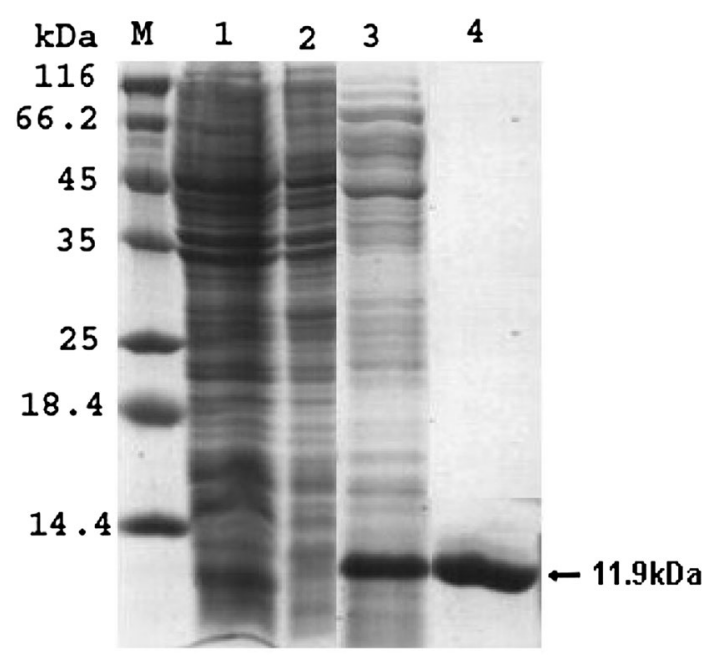

Fig. 1 Coomassie Brilliant Blue stained $15 \%$ SDS-PAGE gel, showing expression of recombinant PE protein. lane $M$ prestained protein molecular weight marker, lane 1 whole cell extract of $E$. coli M15 cells; lane 2 whole cell extract of $E$. coli M15 cells harboring plasmid pQE PE (uninduced), lane 3 whole cell extract of $E$. coli M15 cells harboring plasmid pQE PE (IPTG induced $-6 \mathrm{~h}$ post induction); lane 4 purified recombinant fusion protein His-PE

pQEPE on restriction digestion with, NheI and EcoRI released an identical size fragment on $1.2 \%$ agarose gel. The E. coli M15 cells harboring the plasmid pQEPE on induction for $6 \mathrm{~h}$ with $1 \mathrm{mM} / \mathrm{L}$ IPTG resulting accumulation of insoluble 11.0.2 kDa His-fusion protein detected in total cell extract of $E$. coli., which is corresponding to that predicted for recombinant PE protein (Fig. 1, lane 3). No such protein band was observed with $E$. coli $M 15$ cells or in uninduced $E$. coli $M 15$ cells harboring recombinant plasmid pQEPE (Fig. 1, lanes 1, 2).

\section{Purification of the recombinant PE protein}

The molecular mass of the recombinant PE protein obtained was estimated to be $11.9 \mathrm{kDa}$ by $15 \%$ SDSPAGE (Fig. 1, lane 4). The yield of pure recombinant PE protein was about $18-20 \mathrm{mg} / \mathrm{l}$ of culture.

\section{Immunoreactivity of the recombinant $\mathrm{PE}$ protein}

Western blot analysis using antiserum raised against purified recombinant PE protein (11.0.2 kDa His-fusion protein) in mice revealed a single band at $11.9 \mathrm{kDa}$ with IPTG induced whole cell extract expressing recombinant $\mathrm{PE}$ as well as purified recombinant PE protein (Fig. 2, lanes 3, 4). No such band was visible in M15 cells as well as uninduced total cell extract of M15 harboring pQEPE plasmid (Fig. 2, lanes 1, 2). However, a band of $9.7 \mathrm{kDa}$ was also detected with native protein from Map (Fig. 2, lane 5).

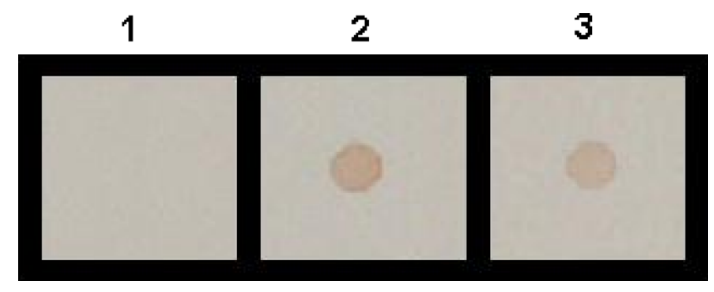

Fig. 2 Dot blot assay of the recombinant PE protein. 1 Recombinant PE protein probed with control sera; 2 recombinant PE protein probed with hyperimmune sera; 3 M.a.paratuberculosis culture sonicate probed with hyperimmune sera

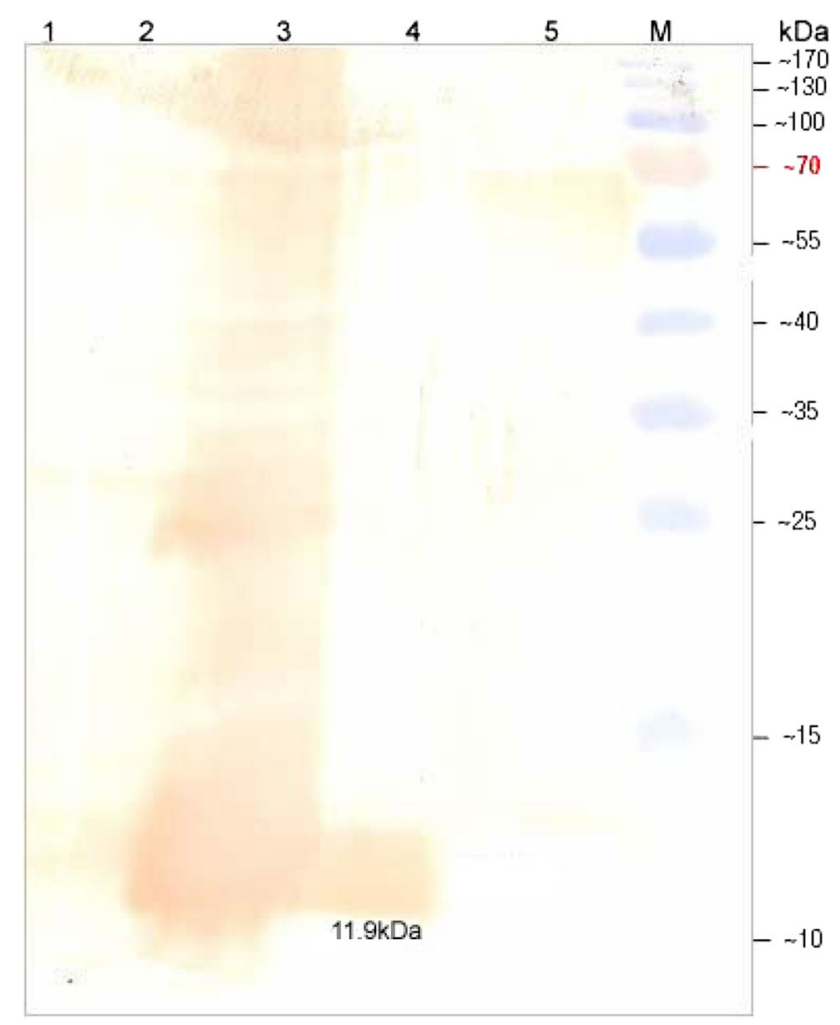

Fig. 3 Western blot assay of the recombinant PE protein. lane 1 whole cell extract of $E$. coli M15 cells; lane 2 whole cell extract of E. coli M15 cells harboring plasmid $\mathrm{pQE} \mathrm{PE}$ (uninduced); lane 3 whole cell extract of $E$. coli M15 cells harboring plasmid pQE PE (IPTG induced $-6 \mathrm{~h}$ post induction); lane 4 purified recombinant HisPE protein; lane 5 sonicated antigen of $M$. a. Paratuberculosis; lane $M$ prestained protein molecular weight marker

Further the recombinant PE protein was also recognized by the serum from goat naturally infected with Map (Fig. 3).

\section{Deduced amino acid analysis}

The nucleotide sequence of the pQEPE plasmid having $300 \mathrm{bp}$ PE gene of Map has been deposited in Gene bank database under accession no. FJ716631. The predicted 99 amino acids of the $300 \mathrm{bp}$ gene fragment had a mature protein of $9.7 \mathrm{kDa}$. Analysis of the deduced 99 amino acids 
Fig. 4 DTH (mean \pm SEM) elicited by purified recombinant PE protein in M.a. paratuberculosis sensitized mice (mean diameter of erythema in $\mathrm{mm}$ ) upon recall with $10 \mu \mathrm{g}$ of the indicated antigen.*Significant difference at $P<0.05$

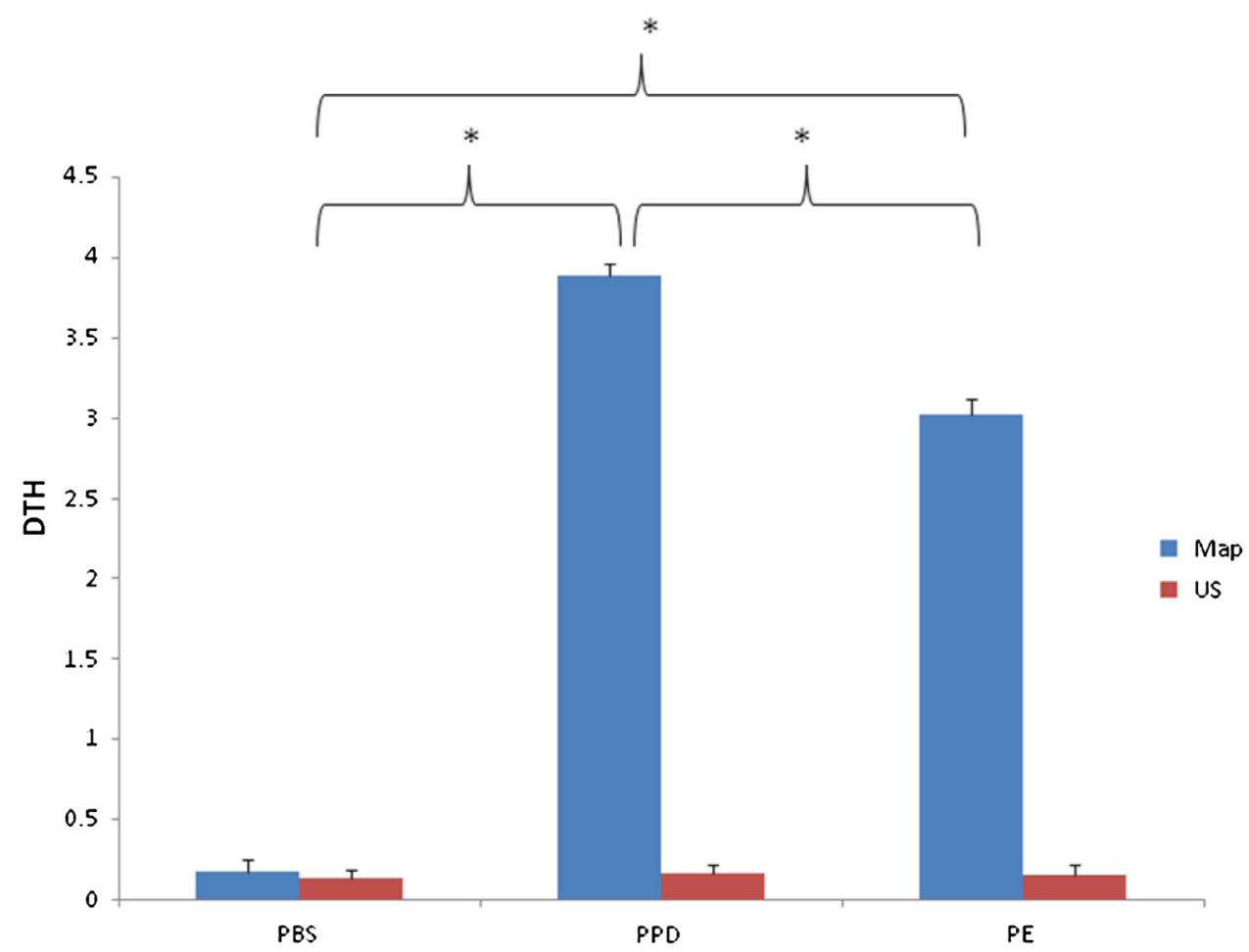

sequence indicated that the protein contained three major hydrophobic regions (amino acids 5-10, 45-50 and 90-95).

\section{Induction of DTH response}

Mice immunized with recombinant PE protein reacted with recombinant PE protein giving skin reaction. However, response to johnin PPD was greater than those to recombinant PE protein; non-immunized animals did not show significant skin reactions to the fusion protein as well as johnin PPD (Fig. 4).

\section{Discussion}

PE family proteins of Mycobacterium species are known to be important antigens for conferring host immune defence. A few antigens from the PE family protein Mtb and Map have reported to elicit $\mathrm{T}$ cell response (Delogu and Brennan 2001) or some of them are involved to mediate humoral immune response (Narayana et al. 2007). The completion of Map genome has provided information about several ORFs from PE family proteins. In the present study, we have selected a sequence of $300 \mathrm{bp}$ from the Map genome and $E$. coli expression system pQE30 UA, to produce $9.7 \mathrm{kDa}$ protein of Map for further studies.

The whole cell extract of E. coli harboring plasmid pQE PE induced by IPTG showed a predominant band of
$11.9 \mathrm{kDa}$ corresponding to expected size of PE fusion protein. The expressed recombinant $6 \mathrm{X}$ His tag fusion protein could be purified by Ni-NTA affinity chromatography. Although a variety of heterologous expression systems have been developed to produce recombinant proteins, the purification of proteins obtained still remains problematic (Goswami et al. 1996). The presence of 6Xhistidine residues at $\mathrm{N}$-terminal of the fusion protein enabled us to purify the protein by single step affinity purification by using Ni-NTA resin (Deb and Goswami 2010). In the present study, recovery of the purified PE fusion protein was more than $90 \%$ after $6 \mathrm{~h}$ of induction. Similarly, cloning in $\mathrm{pQE}$ series expression vector system was utilized to generate high levels of $35 \mathrm{kDa}$ protein of Map (Basagoudanawar et al. 2005) and a $26 \mathrm{kDa}$ protein of Brucella abortus (Kumar et al. 2008) and $34.9 \mathrm{kDa}$ PPE antigen of Map (Deb and Goswami 2010). The polyclonal sera raised in mice against the recombinant His-PE protein recognized both the E. coli expressed PE protein as well as the PE protein in Map culture sonicate on dot and western blot analysis indicating that the immunogenic nature of PE protein was not affected by expression in a heterologous expression system.

Delay type hypersensitivity (DTH) reaction is an indicator of $\mathrm{T}$ cell mediated immunity towards mycobacterial infection (Orme et al. 1993). In the present study we observed the DTH responses in all the animals sensitized with Map using recombinant PE protein as well as johnin PPD. A better response was detected in the groups 
sensitized with Johnin PPD which may be due to polyclonal activation of $\mathrm{T}$ cells by multiple antigenic components in these preparations, compared to the single antigenic component of the recombinant PE protein. These results corroborated with earlier findings by Deb and Goswami (2010). This piece of information may postulate that Map PE may be a potent immune stimulating antigen and can be used as reference antigen for developing novel recombinant therapeutics/diagnostics against paratuberculosis infection.

Acknowledgments The authors are thankful to the Director ICARIVRI, Izatnagar, India for providing the necessary facilities to conduct the present study.

\section{Compliance with ethical standards}

Conflict of interest We declared that none of the authors have any kind of conflict of interest for the present study.

Open Access This article is distributed under the terms of the Creative Commons Attribution 4.0 International License (http:// creativecommons.org/licenses/by/4.0/), which permits unrestricted use, distribution, and reproduction in any medium, provided you give appropriate credit to the original author(s) and the source, provide a link to the Creative Commons license, and indicate if changes were made.

\section{References}

Basagoudanawar SH, Goswami PP, Tiwari V (2005) Cellular immuneresponse to $35 \mathrm{kDa}$ recombinant antigen of Mycobacterium avium paratuberculosis. Vet Res Commun 28:209-224

Bjerrum OJ, Schafer-Nielsen C (1986) In: Dunn (ed) Electrophoresis $86 \mathrm{VCH}$, Weinheim, Germany, pp 315

Brennan MJ (2005) The tuberculosis vaccine challenge. Tuberculosis 85(1):7-12

Brennan MJ, Delogu G (2002) The PE multigene family: a 'molecular mantra' for mycobacteria. Trends Microbiol 10:246-249

Brusasca PN, Colangeli R, Lyashchenko KP, Zhao X, Vogelstein M, Spencer JS, McMurray DN, Gennaro ML (2001) Immunological characterization of antigens encoded by the RD1 region of the Mycobacterium tuberculosis genome. Scand J Immunol 54(5):448-452

Deb R, Goswami PP (2010) Expression of a gene encoding $34.9 \mathrm{kDa}$ PPE antigen of Mycobacterium avium subsp. paratuberculosis in
E. coli. Mol Biol Int 2010. Article ID 628153. doi:10.4061/2010/ 628153

Delogu G, Brennan MJ (2001) Comparative immune response to PE and PE_PGRS antigens of Mycobacterium tuberculosis. Infect Immun 69:5606-5611

Deng W, Zeng J, Xiang X, Li P, Xie J (2015) PE11 (Rv1169c) selectively alters fatty acid components of Mycobacterium smegmatis and host cell interleukin-6 level accompanied with cell death. Front Microbiol 6:613. doi:10.3389/fmicb.2015.0061

Fishbein S, Wyk N, Warren RM, Sampson SL (2015) Phylogeny to function: PE/PPE protein evolution and impact on Mycobacterium tuberculosis pathogenicity. Mol Microbiol 96(5):901-916

Fisher MA, Plikaytis BB, Shinnick TM (2002) Microarray analysis of the Mycobacterium tuberculosis transcriptional response to the acidic conditions found in phagosomes. J Bacteriol 184(14): 4025-4032

Fleischmann RD, Alland D, Eisen JA, Carpenter L, White O, Peterson J, DeBoy R, Dodson R, Gwinn M, Haft D, Hickey E (2002) Whole-genome comparison of Mycobacterium tuberculosis clinical and laboratory strains. J Bacteriol 184(19):5479-5490

Goswami PP, Rupa P, Prihar NS, Garg LC (1996) Molecular cloning of Clostridium perfringens epsilon-toxin gene and its high level expression in E. coli. Biochem Biophys Res Commun 2263:735-740

Khubaib M, Sheikh JA, Pandey S, Srikanth B, Bhuwan M, Khan N, Hasnain SE, Ehtesham NZ (2016) Mycobacterium tuberculosis co-operonic PE32/PPE65 proteins alter host immune responses by hampering Th1 response. Front Microbiol 7:719. doi:10.3389/ fmicb.2016.00719

Kumar S, Tuteja U, Kumar A, Batra HV (2008) Expression and purification of the $26 \mathrm{kDa}$ periplasmic protein of Brucella abortus: a reagent for the diagnosis of bovine brucellosis. Biotechnol Appl Biochem 49(3):213-218

Kyte J, Doolittle RF (1982) A simple method for displaying the hydropathic character of a protein. J Molec Bio 157(1):105-132

Narayana Y, Joshi B, Katoch VM, Mishra KC, Balaji KN (2007) Differential B-cell responses are induced by Mycobacterium tuberculosis PE antigens Rv1169c, Rv0978c, and Rv1818c. Clin Vaccine Immunol 14(10):1334-1341

Orme IM, Andersen P, Boom WH (1993) T cell response to Mycobacterium tuberculosis. J Infect Dis 167(6):1481-1497

Parra M, Cadieux N, Pickett T, Dheenadhayalan V, Brennan MJ (2006) A PE protein expressed by Mycobacterium avium is an effective T-cell immunogen. Infect Immun 74(1):786-789

Portillo PD, Murillo LA, Patarroyo ME (1991) Genetically engineered vaccines: an overview. Plasmid 39:100-113

Voskuil MI, Schnappinger D, Rutherford R, Liu Y, Schoolnik GK (2004) Regulation of the Mycobacterium tuberculosis PE/PPE genes. Tuberculosis 84(3):256-262 